\title{
Integrated Discounting Framework for Indian Brick-and-Mortar Retailers
}

\author{
H. R. Ganesha ${ }^{1}$, P. S. Aithal ${ }^{2}$, \& P. Kirubadevi ${ }^{3}$ \\ ${ }^{1}$ Chief Executive Officer - Consulting Division, Gramss Retail Trading Private Limited, \\ Bengaluru - 560078, India and Post-Doctoral Research Fellow, College of Management \& \\ Commerce, Srinivas University, Mangalore - 575001, India. \\ OrcidID: 0000-0002-5878-8844; E-mail: hrganesha@yahoo.co.in \\ ${ }^{2}$ Vice Chancellor, Srinivas University, Mangalore - 575001, India. \\ OrcidID: 0000-0002-4691-8736; E-mail: psaithal@gmail.com \\ ${ }^{3}$ Head of Category Management and Sourcing, Actoserba Active Wholesale Private Limited \\ (Zivame), Bengaluru - 560038, India. \\ OrcidID: 0000-0003-2291-8448; E-mail: spkirubadevi@yahoo.com
}

Area/Section: Business Management.

Type of the Paper: Research Paper.

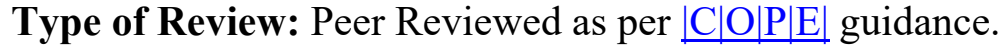

Indexed in: OpenAIRE.

DOI: http://doi.org/10.5281/zenodo.3774700.

Google Scholar Citation: $\underline{\text { IJMTS. }}$

\section{How to Cite this Paper:}

Ganesha, H. R., Aithal, P. S. \& Kirubadevi, P. (2020). Integrated Discounting Framework for Indian Brick-and-Mortar Retailers. International Journal of Management, Technology, and Social Sciences (IJMTS), 5(1), 110-123. DOI: http://doi.org/10.5281/zenodo.3774700.

International Journal of Management, Technology, and Social Sciences (IJMTS)

A Refereed International Journal of Srinivas University, India.

(C) With Authors.

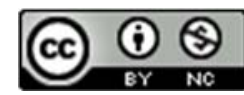

This work is licensed under a Creative Commons Attribution-Non-Commercial 4.0 International License subject to proper citation to the publication source of the work.

Disclaimer: The scholarly papers as reviewed and published by the Srinivas Publications (S.P.), India are the views and opinions of their respective authors and are not the views or opinions of the SP. The SP disclaims of any harm or loss caused due to the published content to any party. 


\title{
Integrated Discounting Framework for Indian Brick-and- Mortar Retailers
}

\author{
H. R. Ganesha ${ }^{1}$, P. S. Aithal ${ }^{2}$, \& P. Kirubadevi ${ }^{3}$ \\ ${ }^{1}$ Chief Executive Officer - Consulting Division, Gramss Retail Trading Private Limited, \\ Bengaluru - 560078, India and Post-Doctoral Research Fellow, College of Management \& \\ Commerce, Srinivas University, Mangalore - 575001, India. \\ OrcidID: 0000-0002-5878-8844; E-mail: hrganesha@yahoo.co.in \\ ${ }^{2}$ Vice Chancellor, Srinivas University, Mangalore - 575001, India. \\ OrcidID: 0000-0002-4691-8736; E-mail: psaithal@gmail.com \\ ${ }^{3}$ Head of Category Management and Sourcing, Actoserba Active Wholesale Private Limited \\ (Zivame), Bengaluru - 560038, India. \\ OrcidID: 0000-0003-2291-8448; E-mail: spkirubadevi@yahoo.com
}

\begin{abstract}
Since the time online retailing format started getting consumer acceptance in India, consumers now have wider options available for them to buy a product at a discounted price and notably, as online stores in India are following the product discounting as one of the key drivers for consumer acquisition, consumers' perspective towards discount at Brick-and-mortar store has changed. This change in consumers' perspective has put the majority of Brick-and-mortar retailers in India into a quandary and they are losing out their market share slowly to online retailers. From the existing literature we have found many discounting frameworks suggested by researchers, but they are all isolated for specific contexts and leave it to retailers to create their own discounting frameworks. In this work, we have attempted to create an integrated discounting framework for Indian brickand-mortar retailers by carrying out multiple experiments with different manipulations and under different contexts along with taking clues from past research findings, insights and suggestions along with testing validity and reliability of the proposed framework in the field.
\end{abstract}

Keywords: Discount, End-of-season sale; Brick-and-mortar store; Offline store; Physical store; Consumer perspective; Online store; Sales promotion; Discount Framework; Short-Term Discounts; Long-Term Discounts; Decentralized Discounts.

This ongoing change in penetration is projected

\section{INTRODUCTION :}

The e-commerce retailing format undoubtedly making a paradigm shift in the way retailing is done in India. This new retailing format, ecommerce is projected to get larger in size to 62.3 billion US\$ by the year 2023 which is at 32.34 billion US\$ in the year 2019. Such a significant improvement in the share can be attributed mostly to rapidly increasing penetration of smartphones and internet users. to increase the total internet user base to 657.8 million by the year 2023 which is at 553.7 million as of the year 2019 in India. Share of buyers using e-commerce retailing format in India is all set to become 50.03 percent by 2020 which is at 23.55 percent as of the year 2016 (Statista) [1]. The overall market size of the Indian Retail industry which was at 950 billion US\$ in the year 2018 might cross 1.1 trillion US\$ by the year 2020 (IBEF) [2]. E-commerce has been able to expand its market consistently in India. Owing to this new retailing format consumers now have the widest product assortment offered to them at 
discounted prices. E-commerce retailing format has probably crossed a key milestone in revolutionizing the Indian retail market, and this trend is expected to continue for many more years. As per one IBEF's December 2019 [2] report on Indian retailing, it is noted that the union government of India is also working on various ways to boost consumption in the rural market of India and e-commerce will have its significant contribution in achieving this. Forecast also indicates e-commerce retailing will be able to capture 7 percent of the overall Indian retail market by 2021 .

In such a short period e-commerce retailing format in India reached to around 3 percent of the overall Indian retail market. Growth rate is more than double as compared to the Brick-and-mortar stores. Available literature indicates to key reasons for this as being capable of building the trust of the consumers in online stores, they have successfully established their brands in the minds of the online shoppers through their 365 days discounts, deals and low-price strategies. Even though it is very hard to build a sustainable business model using strategies mainly based on price wars, it is inevitable that the brick-andmortar stores in India will have to ascertain specific strategies head-on to deal with this increasing loss of market share to online stores. Up till the emergence of online stores in India, brick-and-mortar retailers were following a season and occasion driven sale promotions prominently known as end-of-season sale and festive sale which accounted for close to 40 percent of their annual revenue. But, post the emergence of online stores in India, the majority of brick-and-mortar retailers in India are bewildered with continuous discounts, deals, sale promotion events, coupons being offered by the online stores throughout the year and they are not able to design appropriate sales promotion programmes.

\section{LITERATURE REVIEW :}

We have noted that, for many, the choice of store format was and is one of the important research subjects among many researchers beginning from the 70's of the 20th century. The authors of many of earlier studies - among others: Monroe \&
Guiltinan (1975) [3], Arnold, Oum \& Tigert (1983) [4], Mason, Durand \& Taylor (1983) [5], Keng \& Ehrenberg (1984) [6], Louviere \& Gaeth (1987) [7], Spiggle \& Sewall (1987) [8], Dawson, Bloch \& Ridgway (1990) [9], Burke et al. (1992) [10], have studied to rationalize store choice using different approaches, models and frameworks with respect to internal and external factors to the consumer such as (a) store attributes (b) situational factors, (c) consumers' households, (d) consumers' demographics, (e) consumers' shopping patterns, (f) consumers' attitudes toward stores, (g) implied importance, and (h) weightage of price levels. It is also noted that most of the above said studies were carried on same store formats (supermarkets and discount stores).

Weitz (1979) [11], believes that the way in which sales personnel interact with consumers needs to be customized to each consumer and this could possibly be able to determine their success. Saxe and Weitz (1982) [12], were the first to define sales personnel's consumer orientation. This customer orientation is said to happen when the sales personnel and consumer together practice the marketing concept. They have clearly stated that just the interaction between sales personnel and consumer does not yield to this orientation, it needs to encompass most of the marketing concepts driven centrally by the company. Later, Brown et al. (2002) [13] narrowed down this definition and came up with two key constructs, the first one being sales personnel's tendency to ensure consumer needs are met and the second one being the level of sales personnel's enjoyment in doing so. Vandewalle et al. (1999) [14], what can lead to sales personnel enjoy the process of interaction with consumers and ultimately selling a product is their strong orientation to learning.

Gupta and Cooper (1992) [15], have demonstrated that brand reputation plays an important role in creating consumer perceptions over discounting announcements. Hence discount level alone will not be able to determine the changes in consumers intent to buy more. We have also noted that few studies have examined the relationship between consumer shopping behaviour and retail pricing format (Bell, Ho \& 
Tang, 1998) [16], particularly this relationship is stronger when one store format is priced higher than another. Chandon et al. (2000) [17], suggested that the discount types and levels need to be relevant to the products/category to enhance consumer preference to buy more.

Shim et al. (2000) [18], using consumer's shopping behavioural intentions was able to determine three different segments of market in relation to consumer's shopping behaviour, such as (a) primarily Internet shopper, (b) productsituation specific cross-shopper, and (c) primarily store-oriented shopper markets across (a) cognitive, and (b) sensory products. One of the key recommendations from the researchers was that the retailers and mall developers should understand the greater importance of social influence on online shoppers and cross-shoppers, as compared to traditional store shoppers. Perhaps a competitive strategy could be utilized whereby promotions portray aspirational and/or peer members of Internet consumers describing their positive experiences as mall patrons.

As per Peter and Olson (2002) [19], consumer preference for a particular retail channel and format is influenced by many internal and external factors viz., changes in the overall industry, the economy, price level, convenience, time required for shopping, demographics and personality of consumer. Bhatnagar, \& Ratchford (2004) [20] were able to find an optimal condition by manipulating total cost and price levels between different retailing formats which can influence the consumer choice of retailing format. Hardesty and Suter (2005) [21] argue that, post the online retailing format emergence, consumers' expectations on lower priced products has increased.

Diwakar Gupta et. al (2006) [22], argue that it is very difficult to set clearance prices or discount levels for liquidating stocks and this problem is even worse towards the end of EOSS. Most importantly the impact of change in discount level towards the end of EOSS have shown minimal impact on consumer demand. Few researchers were also able to develop methods of arriving at optimal prices during EOSS period and they have also indicated that, even though the impact of EOSS is positive as far as clearance of old inventory is concerned it holds valid only for shorter period of time (Wierenga \& Soethoudt, 2010) [23], because these are perceived by the consumer as an immediate benefit (Yusuf, 2010) [24]. As per findings of research studies conducted by Teunter (2002) [25], Wierenga and Soethoudt (2010) [23], a significant share of overall sales is contributed by the sales revenue represented by promotional events and activities by the retailers. Few researchers have also indicated that there still exists huge gap in understanding of the relationship between consumer purchase behaviour and sales promotional events both at the theoretical and practical levels (D'Austous \& Landreville, 2003 [26]; Haans \& Gijsbrechts, 2011 [27]).

Mokhtarian and Tang (2009) [28], suggested that the key influencers in the consumer retail channel or format choice are the key characteristics of a retail channel or format as perceived by the consumer and the same is different at different stages of consumer's purchase decision-making process. Dhruv et. al (2017) [29]. One of the key components of their organizing framework for 'future of retailing' identified by them was 'visual display and merchandise offer decisions' along with other four components 1) technology and tools to facilitate decision making, 2) consumption and engagement, 3) big data collection and usage and 4) analytics and probability.

Ganesha, H.R. et al. (2020) [30], concluded that it is practically impossible to change consumers perspective towards a discount in favour of Brick-and-mortar store as the same is widely influenced by a paradigm shift in the evolution of various modern retailing formats available now to consumers to buy required products. It was evident from their empirical research that Brickand-mortar retailer will no more be able to convert walk-ins into bills unless the discount is one of the key components of their selling proposition, but possibly retailer can analyse their sales data on a consistent basis to determine ideal levels of discount which can probably gain a competitive edge over online stores on the discount component and arrest such huge degrowth in their store profitability. Ganesha, H.R. et al. (2020) [31], conducted multiple short- 
term discounting experiments and compared the findings with past ten years empirical data and concluded that; 'discounts, if offered to select consumers on select product/category for a shorter period of time, could possibly (a) attract only relevant consumers who were planning to purchase these products, (b) distract consumers for whom the product/category on discount offer is either irrelevant or already being bought, (c) create a perception in consumers mind about discount levels available at their Brick-andmortar store higher than that of an online store on a consistent basis, (d) negate the loss or reduced gross earnings in the discounted product/category through regular sales from non-discounted products/categories. And thereby (a) positively impacting the overall store level profits and (b) creating sustainable competitive edge with online stores over the discount component'. Ganesha, H.R. et al. (2020) [32], conducted multiple longterm discounting experiments and compared the findings with past ten years empirical data and concluded that; 'discounts, if offered to select consumers on select product/category for a longer period of time which allows consumers to create favourable perceptions towards the store, could possibly (a) attract only relevant consumers who were planning to purchase these products, (b) distract consumers for whom the product/category on discount offer is either irrelevant or already being bought, (c) create a perception in consumers mind about discount levels available at their Brick-and-mortar store being usually higher than that of an online store on a consistent basis, (d) negate the loss or reduced gross earnings in the discounted product/category through regular sales from nondiscounted products/categories. And thereby (a) positively impacting the overall store level profits and (b) creating a sustainable competitive edge with online stores over the discount component'. Ganesha, H.R. et al. (2020) [33], conducted a long-term decentralized discounting experiment and concluded that; 'the experiment of decentralizing the discount offers along with empowering the sales personnel who are the closest link between the retailer/brand and the consumers have clearly shown significant improvement in overall store profitability. This, in turn, suppress the fact that it is not just the discount level, type, duration, coverage, and advertising discount offer which is important to attract more consumers and increase their intent to purchase more, what is also very important is (a) how does the sales personnel who is dealing with the consumer directly and has real-time insights about consumer's intent, needs and attitude towards a particular purchase activity communicate available discount offers to consumers with confidence, (b) does he/she believes in a particular discount offer and (c) can he/she convince the consumer about the benefits of discount offers which are not real-time. What is very important is the retailer's understanding of existing consumer base, their purchase history, their purchase behaviour, their response to different types, their life-stage needs, product/category usage frequencies and levels of discounts previously offered and most of this information and the decision to offer a relevant discount to the consumer in real-time is easier when the sales personnel is empowered to do so'. From the existing literature we have found many discounting frameworks suggested by researchers, but they are all isolated for specific contexts and leave it to retailers to create their own discounting frameworks. In this work we have attempted to create an integrated discounting framework for Indian brick-andmortar retailers by carrying out sixteen experiments under different contexts along with taking clues from past research findings, insights and suggestions.

\section{OBJECTIVES:}

Key objectives of this research were to;

(a) understand the change in overall store profitability by applying multiple discounting frameworks across; (i) control group, (ii) experimental group, (iii) pre-test period, (iv) post-test period, (v) pre-online stores emergence period and (vi)post-online stores emergence period,

(b) analyse all the discounting frameworks post experimentation, 
(c) shortlist and assign proven discounting frameworks in relation to the context of discounting,

(d) design an integrated framework deriving insights based on the assignment process and outcomes.

\section{METHODOLOGY:}

Stage I: One organized Brick-and-mortar retailer in India was selected who is having stores all over India across (a) mall stores, (b) high-street stores,(c) neighbourhood stores,(d) tier 1,2 and 3 cities, (e) offering multiple-categories and multiple-brands at mid to high price positioning catering to pregnant women, new moms, babies, infants and kids up to 8 years.

\section{Stage II:}

i. Retailer perspective: The entire population (388 employees) across various functions/department such as (1) management and strategy, (2) marketing and communication, (3) category management, (4) supply chain management, (5) finance and accounts, (6) IT and support functions, (7) human resource department, (8) sales and operations, (9) store sales staff of the select Brick-and-mortar retailer were interviewed under controlled environment through google sheets to collect information regarding their perspective towards discounts at brickand-mortar stores pre and post emergence of online stores.

ii. Consumer perspective: A random sample (2712 customers) of customers of the select Brick-and-mortar retailer were interviewed under a controlled environment through close-ended questions to collect information regarding their perspective towards discounts at brick-and-mortar stores pre and post emergence of online stores.

Stage III: Data for all the stores was collected prior to all the experimentations (pre-test).

Stage IV: Multiple discounting frameworks were experimented over a period of eleven months (experimental phase).

Stage V: Results obtained during the experimentation stage (post-test) analysed using appropriate statistical methods and compared with the pre-test period.

Stage VI: The findings from this experimentation were compared with the results of empirical research previously carried out on the impact of changes in retailer and consumer perspective towards discount post emergence of online stores in India.

Stage VII: Insights and inferences from the research findings were used to propose an integrated discounting framework for Indian Brick-and-mortar retailers.

Stage VIII: In this stage, the proposed integrated discounting framework was applied across all the stores over a period of 30 days to test the validity and reliability of the framework in the field.

\section{DETAILS OF EXPERIMENTS :}

Table 1: Key differences and comparisons across all the experiments.

\begin{tabular}{|c|c|c|c|c|c|}
\hline $\begin{array}{l}\text { Experiment } \\
\text { Code }\end{array}$ & Type & $\begin{array}{l}\text { Duration } \\
\text { (in days) }\end{array}$ & $\begin{array}{l}\text { Inventory } \\
\text { Coverage }\end{array}$ & $\begin{array}{l}\text { Management } \\
\text { Control }\end{array}$ & $\begin{array}{c}\text { Key Objective in } \\
\text { Relation to Online } \\
\text { Stores }\end{array}$ \\
\hline $0 \mathrm{~A}$ & Pre-online & 45 & All old stocks & Centralized & Not applicable \\
\hline $\mathrm{OB}$ & Post-online & 60 & All stocks & entralized & Gain competitive edge \\
\hline 1 & Short-tenm & 8 & All stocks & Centralized & Gain competitive edge \\
\hline 2 & Short-tenn & 3 & Specific category & Centralized & Gain competitive edge \\
\hline 3 & Short-tem & 3 & Specific categary & Centralized & Gain competitive edge \\
\hline 4 & Short-temn & 3 & Specific category & Centralized & Gain competitive edge \\
\hline 5 & Short-tenn & 3 & Specific category & Centralized & Gain competitive edge \\
\hline 6 & Short-tem & 3 & Specific category & Centralized & Gain competitive edge \\
\hline 7 & Short-tem & 1 & All stocks & Centralized & Gain competitive edge \\
\hline 8 & Short-tem & 1 & All stocks & Centralized & Gain competitive edge \\
\hline 9 & Short-term & 1 & All stocks & Centralized & Gain competitive edge \\
\hline 10 & Long-tem & 35 & All stocks & Centralized & Gain competitive edge \\
\hline 11 & Long-tem & 25 & All old stocks & Centralized & Gain competitive edge \\
\hline 12 & Long-term & 25 & All old stocks & Centralized & Gain competitive edge \\
\hline 13 & Long-term & 25 & All old stocks & Centralized & Gain competitive edge \\
\hline 14 & Long-term & 82 & Specific product & Centralized & Gain competitive edge \\
\hline 15 & Long-term & 28 & Specific product & Centralized & Gain competitive edge \\
\hline 16 & Long-term & 43 & Specific product & Centralized & Gain competitive edge \\
\hline 17 & Long-tem & 333 & All stocks & Decentralized & Gain competitive edge \\
\hline
\end{tabular}

Table1: (continued): Key differences and comparisons across all the experiments. 


\begin{tabular}{|c|c|c|c|c|c|}
\hline $\begin{array}{l}\text { Experiment } \\
\text { Code }\end{array}$ & $\begin{array}{l}\text { Competition Level } \\
\text { with Online Stores }\end{array}$ & $\begin{array}{c}\text { Level of } \\
\text { Customized to } \\
\text { Select } \\
\text { Consumers }\end{array}$ & $\begin{array}{l}\text { In-Store } \\
\text { Signages \& } \\
\text { SMS to Existing } \\
\text { Consumers }\end{array}$ & ATL & $\begin{array}{c}\text { Benchmark } \\
\text { Availabilty for } \\
\text { Consumers } \\
\text { with 0nline } \\
\text { Stores }\end{array}$ \\
\hline $\mathrm{OA}$ & Not applicable & Low & Yes; to all & Yes & Not applicable \\
\hline$O B$ & Head-on (direct) & Low & Yes; to all & Yes & Yes \\
\hline 1 & Indrect & Low & Yes; to all & No & Yes \\
\hline 2 & Head-on(direct) & High & Yes; to select & No & Yes \\
\hline 3 & Head-on(direct) & High & Yes; to select & No & Yes \\
\hline 4 & Head-on (direct) & High & Yes; to select & No & Yes \\
\hline 5 & Head-on (direct) & High & Yes; to select & No & Yes \\
\hline 6 & Head-on (direct) & High & Yes; to select & No & Yes \\
\hline 7 & Indirect & Low & Yes; to all & No & Yes \\
\hline 8 & Indrect & Low & Yes; to all & No & Yes \\
\hline 9 & Indrect & Low & Yes; to all & No & Yes \\
\hline 10 & Indirect & Low & Yes; to all & No & Yes \\
\hline 11 & Indrect & Low & Yes; to all & No & Yes \\
\hline 12 & Head-on (direct) & Low & Yes; to all & No & Yes \\
\hline 13 & Head-on (direct) & Low & Yes; toall & No & Yes \\
\hline 14 & Matched to online & High & Yes; to select & No & Yes \\
\hline 15 & Head-on (direct) & High & Yes; to select & No & Yes \\
\hline 16 & Just above online & High & Yes; to select & No & Yes \\
\hline 17 & Head-on (indirect) & High & No & No & Yes \\
\hline
\end{tabular}

Based on a qualitative survey of consumers shopping at the retail store which has undergone multiple discounting experimentations, strongly believe that, before the emergence of online stores, discounts at a Brick-and-mortar store were offered basis the age of the inventory that too during specific periods (July and January) widely known as EOSS which was considered to be a shopping festival for which they used to eagerly await for. But, post-online stores emergence, discounts are available for them throughout the year and hence discount has become one of the most important factors for them to make any buying decisions. It is practically impossible for consumers to buy any products at an original price. This significant change in consumers perspective towards discounts is forcing them to not increase their average transaction values per visit to any Brick-and-mortar store thereby making the retailer to lose gross margins and in turn store profitability. Empirical data of ten years (which includes data for pre and post online emergence periods) of a select Brick-and-mortar retailer strongly conforms with most of the beliefs of consumers and retailers on changes in consumer perspective towards discount post emergence of online stores across. But the data clearly indicates that a) retailer has not followed any strategical way of offering discounts b) retailer is carried away by perceptions/beliefs of store sales staff and consumers, c) discounts have been increased by 2.202 times without any significant improvement in the conversions and average transaction values per consumer. Owing to these changes in consumer perspective towards discount retailer is now making 4.249 times lesser profit as compared to pre-online stores emergence.

Results of multiple short-term discounting experiments (experiment codes1, 2, 3, 4, 5, 6, 7, 8 and 9) indicate that the discount levels, discount types, discount duration and discount coverage impact consumer attraction and overall store profitability levels. Some have a positive impact and some negative. It is important to note that, ten years of empirical data and these nine experimentations though indicate a significant positive correlation ( 0.269 at 0.01 level 2 -tailed with Sig. value of 0.000) between discount and consumer attraction it also shows that the overall store profitability is significantly correlated negatively with discounts $(-0.665$ at 0.01 level 2tailed with Sig. value of 0.505$)$.

Results of multiple long-term discounting experiments (experiment code 10,11, 12, 13, 14, 15 and 16) indicate that the discount levels, discount types, discount duration and discount coverage impact consumer attraction and overall store profitability levels. Some have positive impact and some negative. It is important to note that, ten years of empirical data and these seven experimentations though indicate a significant positive correlation $(0.407$ at 0.01 level 2-tailed with Sig. value of 0.000 ) between discount and consumer attraction it also shows that the overall store profitability is significantly correlated negatively with discounts $(-0.658$ at 0.01 level 2tailed with Sig. value of 0.054$)$.

In the decentralized discounting experiment (experiment code 17), we have found that the real treatment effect has shown a 3.541 times improvement in the overall store profitability of the experimental group over their pre-test period 
which is significant. When compared with different periods indicate that the discount levels and the way in which the discount is offered to impact consumer attraction and overall store profitability levels. In the experimental group post-test, we have found a significant positive correlation $(0.886$ at 0.01 level 2 -tailed with t-test Sig. value of 0.000 ) between discount and consumer attraction and a significant positive correlation between discounts and overall store profitability $(0.774$ at 0.01 level 2 -tailed with a ttest Sig. value of 0.145 ) whereas in the control group we have found a positive correlation $(0.446$ at 0.01 level 2-tailed with a t-test Sig. value of 0.000 ) between discount and consumer attraction and a positive correlation between discounts and overall store profitability $(0.205$ at 0.01 level 2tailed with t-test Sig. value of 0.049) which is not statistically significant.

Table 2: Percent change in key factors across experiment types over post-online period.

Factors

Centralized Decentralized Discounting Discounting

\begin{tabular}{|c|c|c|c|}
\hline Average selling price & $4 \%$ & $\Delta$ & $3 \%$ \\
\hline Average transaction vahue & $\Rightarrow 1 \%$ & $\Delta$ & $-14 \%$ \\
\hline Average basket size & 추 $-3 \%$ & $\forall$ & $-16 \%$ \\
\hline Discount per cent & 合 $-21 \%$ & y & $-44 \%$ \\
\hline Bills per day per square foot & $\sqrt{4} \%$ & A & $83 \%$ \\
\hline Sale quantity per day per square foot & $5 \%$ & 个 & $54 \%$ \\
\hline Discount value per day per square foot & A $-21 \%$ & ฟ & $-29 \%$ \\
\hline Revenue per day per square foot & $\sqrt{11 \%}$ & 个 & $59 \%$ \\
\hline Earning per day per square foot & 대 $0 \%$ & 个 & $21 \%$ \\
\hline Profit per day per square foot & $39 \%$ & 个 & $147 \%$ \\
\hline
\end{tabular}

Table 3: Percent change in key factors across experiment types over post-online period.

\begin{tabular}{|c|c|c|}
\hline Factors & Short-Term & Long-Term \\
\hline Average selling price & A $19 \%$ & $\sqrt{1 \%}$ \\
\hline Average transaction value & $20 \%$ & 남 $-6 \%$ \\
\hline Average basket size & A $0 \%$ & $\Rightarrow-7 \%$ \\
\hline Discount per cent & $-54 \%$ & A $-20 \%$ \\
\hline Bills per day per square foot & 는 $26 \%$ & 는 $22 \%$ \\
\hline Sale quantity per day per square foot & $\Rightarrow 25 \%$ & $12 \%$ \\
\hline Discount value per day per square foot & 님 $-39 \%$ & A $-20 \%$ \\
\hline Revenue per day per square foot & A $50 \%$ & $\sqrt{14 \%}$ \\
\hline Eaming per day per square foot & $\Rightarrow 6 \%$ & $\Rightarrow 3 \%$ \\
\hline Profit per day per square foot & $\Rightarrow 95 \%$ & $53 \%$ \\
\hline
\end{tabular}

Table 4: Percent change in key factors across experiment types over post-online period.

Factors

Low High

Customization Customization

Average selling price

Average transaction value

$\checkmark 2 \% \quad 1 \%$

Average basket size

슨 $-1 \%$ 넨 $-6 \%$

Discount per cent

2. $-3 \% \Rightarrow-7 \%$

Bills per day per square foot

ค $-15 \%$ ค $-20 \%$

Sale quantity per day per square foot

Discount value per day per square foot

Revenue per day per square foot

Eaming per day per square foot

4 $5 \%$ 나 $22 \%$

Profit per day per square foot

\begin{tabular}{|c|c|c|}
\hline $2 \%$ & 핌 & $12 \%$ \\
\hline$-17 \%$ & 令 & $-20 \%$ \\
\hline $5 \%$ & $\Delta$ & $14 \%$ \\
\hline$-3 \%$ & $\Rightarrow$ & $3 \%$ \\
\hline $23 \%$ & 삼 & $53 \%$ \\
\hline
\end{tabular}

Table 5: Percent change in key factors across experiment types over post-online period.

\begin{tabular}{|c|c|c|c|c|}
\hline Factors & $\begin{array}{c}\text { All } \\
\text { Stocks }\end{array}$ & $\begin{array}{c}\text { Old } \\
\text { Stocks }\end{array}$ & $\begin{array}{l}\text { Single } \\
\text { Categoly }\end{array}$ & $\begin{array}{l}\text { Single } \\
\text { Product }\end{array}$ \\
\hline Average selling price & $\sqrt{2} \%$ & $7 \%$ & 1 $15 \%$ & ไ) $13 \%$ \\
\hline Average transaction value & 닐 $-1 \%$ & $-4 \%$ & ก $11 \%$ & $9 \%$ \\
\hline Average basket size & ㄱ. $-3 \%$ & 님 $-11 \%$ & $-4 \%$ & - $-4 \%$ \\
\hline Discount per cent & $-15 \%$ & y $-49 \%$ & $\sqrt{ }-59 \%$ & $\Rightarrow-41 \%$ \\
\hline Bills per day per square foot & $5 \%$ & $\sqrt{7} 64 \%$ & $\Rightarrow 40 \%$ & $\sqrt{17 \%}$ \\
\hline Sale quantity per day per square foot & $\Downarrow 2 \%$ & $44 \%$ & $35 \%$ & $12 \%$ \\
\hline Discount value per day per square foot & $-17 \%$ & y $-37 \%$ & $\sqrt{ }-49 \%$ & y. $-41 \%$ \\
\hline Revenue per day per square foot & $\Downarrow 5 \%$ & $55 \%$ & $56 \%$ & $\Rightarrow 28 \%$ \\
\hline Eaming per day per square foot & $-3 \%$ & $20 \%$ & $26 \%$ & $\checkmark-17 \%$ \\
\hline Profit per day per square foot & $\Downarrow 23 \%$ & $143 \%$ & $173 \%$ & $\checkmark 4 \%$ \\
\hline
\end{tabular}




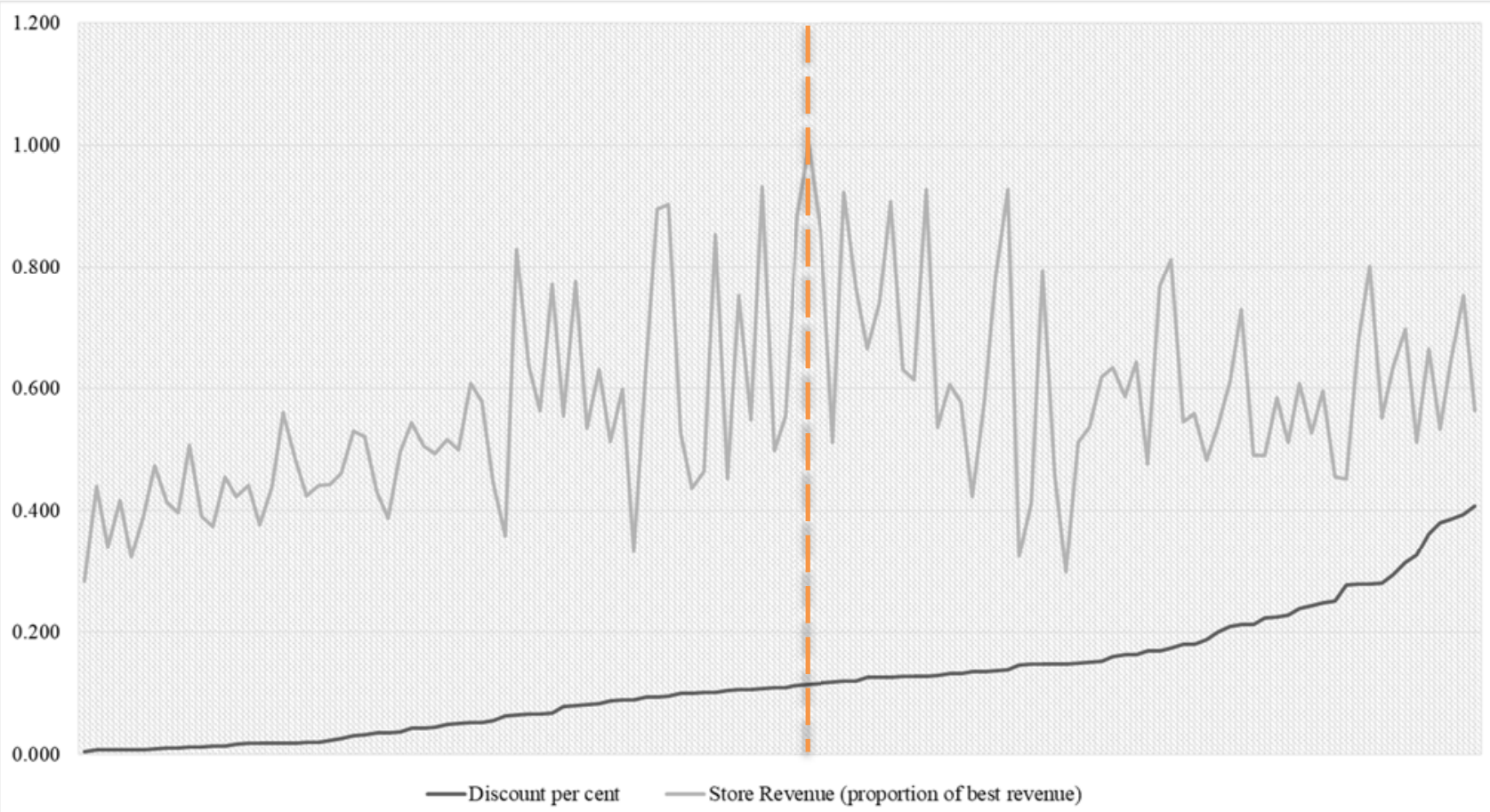

Chart 1: Annualized discount levels and relative store revenue in proportion to best revenue level. Green dotted line showing the ideal level of discount for the best possible store revenue and profit level.

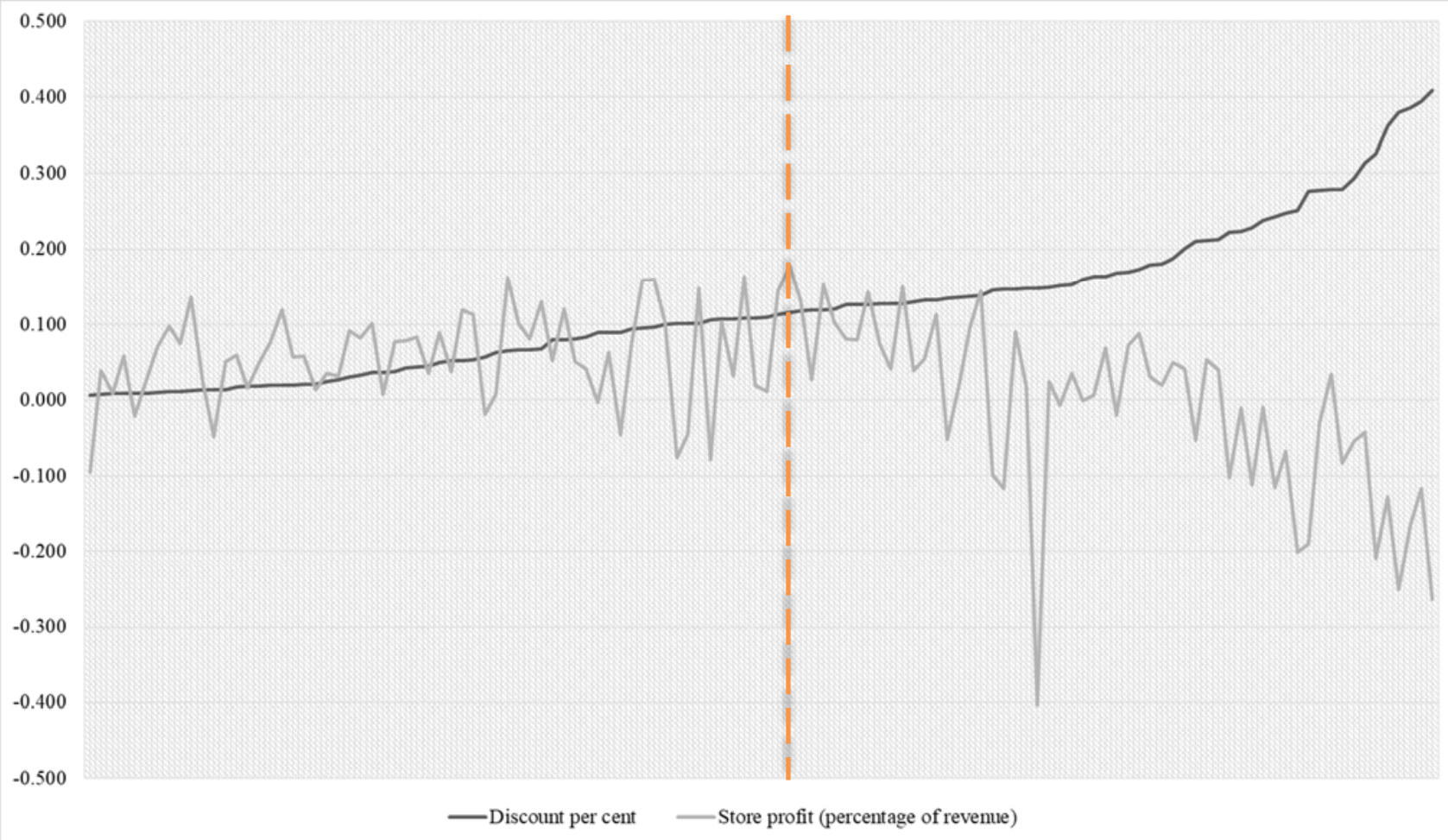

Chart 2: Annualized discount levels and relative store profit as a percentage of store revenue. Green dotted line showing the ideal level of discount for the best possible store revenue and profit level. 
It is evident from multiple statistical analysis that, the discount is an important factor in attracting consumers across the experimental group, control group, pre-test period and post-test period. But as far as overall store profitability is concerned, the results show that even though the levels of discounts were almost similar among multiple experiments and periods, the improvement in overall store profitability was different across multiple experiments in comparison to postonline period as shown in table 2, 3, 4 and 5.It is also clear that there isn't a single and standard discounting type which can be applied across different contexts.

\section{PROPOSED INTEGRATED DISCOUNTING FRAMEWORK :}

Based on qualitative and quantitative results from surveys and multiple experimentations we propose an integrated discounting framework for Indian brick-and-mortar retailers to gain a competitive advantage over online retailers on the discount component. Any discounting method before its application, the retailer must categorize all the products/categories in their offering into(a) low, (b) medium and (c) high based on (I) explicit product need and need fulfilment frequency and (II) like-for-like availability of product at online stores which enables consumers to compare discounts available at online stores for similar products/brands. Once the categorization of products/categories is done, the retailer needs to allocate appropriate discounting methodology as indicated in the proposed framework 1 which comprises of; (i) type of control (centralized; decentralized), (ii) consumer orientation (customised; un-customized), (iii) duration (short-term; long-term), (iv) coverage (only on old stocks; on all stocks; on specific category; on the specific product). Table 6 defines these key elements further.

With reference to chart 1 and 2 which are plotted based on 120 different levels of discounts ranging from 0.005 to 0.408 percent on original product price are able to showcase an ideal level of discount shown through a vertical dotted line and the same is between 0.11 to 0.12 percent on original product price. This ideal level producing the highest level of revenue and store profit was the result of applying the proposed integrated discounting framework at all the stores belonging to the select retailer in the experimentation. The integrated framework proposed does not in any manner states that by offering a flat discount between 0.11 to 0.12 percent on the original product price yields the highest revenue and store profit. The suggested ideal level is an annualized discount percent and not a constant number throughout a financial year. Retailer can decide to offer any level of discount as long as the annualized discount level of the store remains within the proposed ideal level.

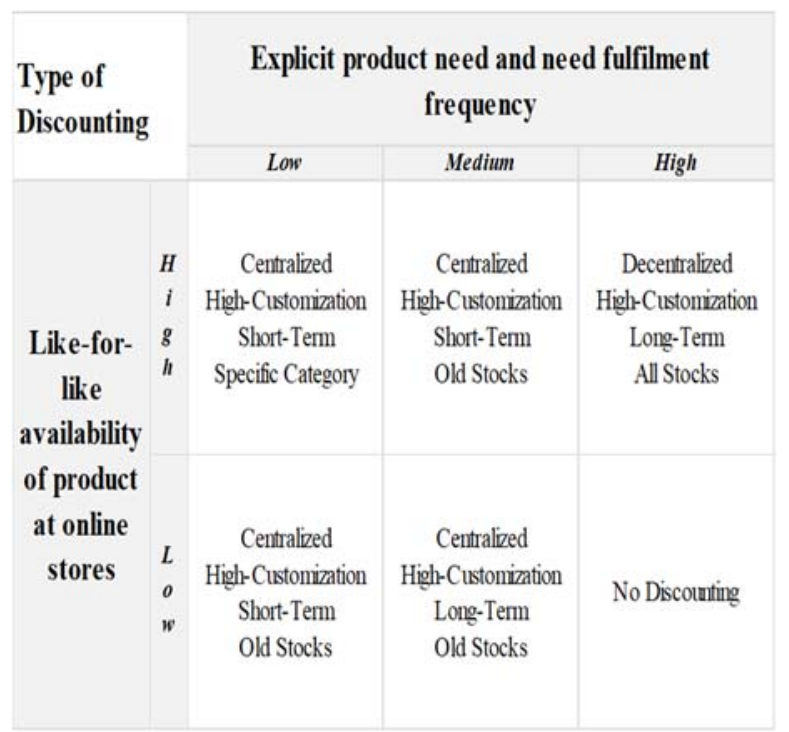

Framework 1: Proposed integrated discounting framework. 
Table 6: Definition of key elements of the proposed integrated discounting framework.
Key elements of the framework
III. Discount type
(i) Centralized Discounting
(ii) Decentralized Discounting
(iii) Short-Term
(iv) Long-Term
(v) Customized
(vi) Un-customized
(vii) All Stocks
(viii) Old Stocks
(ix) Single Category
(x) Single Product

I. Explicit product need and need fulfilment frequency

II. Like-for-like availability of product at online stores

\section{CONCLUSION :}

Discount is a complex component and makes the discounting phenomenon furthermore complicated to understand. It is not just about understanding the ideal type, duration, consumer orientation level, product/category coverage and the level of discount. It is all about understanding the role of every product/category and consumers in relation to the overall business goal of the retailing format and applying different discounting methods in relation to prevailing competition as far as the discount component is concerned. The integrated discounting framework proposed does take this complexity into consideration and gives clear guidelines in its application and in a way reduces the implicit complexity of the discounting phenomenon as a whole. When we applied the proposed integrated discounting framework for a period of 30 days across all the stores of a select retailer, stores delivered the highest ever revenue and profit at an annualized discount of just 0.116 percent in turn providing validity and reliability of the proposed framework in the field.

\section{SUGGESTIONS :}

Brick-and-mortar retailers need to clearly understand every other retail format's key business goal behind using the discount component as one of the key factors of the sales proposition. Few may be trying to capture the bigger market share, few may be trying to show exponential growth in their revenue to attract
Definition

Obvious and stated need/frequency of product requirement;

a) low - once in a year, b) medium - once in three months, c) once in a month Similar product traceable at SKU level

Controlled by retailer's head office team

Sales persomel empowered with maximum limit

one to seven days

one month to one year

Specifically designed and communicated to a relevant group of consumers Designed and communicated all the potential consumers

Applicable on all the stocks available in the store

Stocks which are aged beyond 180 days in the system

Group of variety of products serving a common consumer purpose

Specific product pertaining to a brand

more investors, few may be trying to wrap up their business and few may be assuming that all these consumers acquired based on discount as one of their key components of selling proposition are going to be loyal to their store forever. What is very important is the key business goal of your retailing format and business, clearly understand your product/category assortment/offering in relation to consumers and their needs using both qualitative and quantitative methodologies and make modifications to the proposed integrated discounting framework more often to gain a competitive edge over any retailing formats on the discount component.

\section{LIMITATIONS :}

The main limitation of this research work is the coverage of the various stakeholders viz., consumers and retailers in experimenting with all the seventeen discounting frameworks. This might limit the generalizability of the research findings to other set of retailers and consumers. The second limitation would be the empirical validation is restricted to one retail format i.e., multi brand and multi category baby care stores in India and hence the generalizability of the findings and suggestions to other retail formats. The third limitation would be our ability to carry out true experimental design, but most of for the majority of experiments we have followed pretest post-test control group experimental design. However, it provides significant input regarding the ways to apply this integrated discounting 
framework as the same was derived from findings multiple experiments spread over eleven months and validated with actual empirical transactional data across different periods over a period of ten years.

\section{SCOPE FOR FURTHER RESEARCH :}

It is recommended that the proposed integrated discounting framework to be experimented by researchers and finetune the framework if required. Based on the key growth objectives for a specific period and specific context, brick-andmortar retailers can implement this integrated framework at their select stores and finetune the same based on real-time findings which can then be implemented across the entire chain of their stores.

\section{REFERENCES:}

[1] https://www.statista.com/statistics/289770 le-commerce-revenue-forecast-in-india/. Referred on $15^{\text {th }}$ April 2020.

[2] https://www.ibef.org/industry/retailindia.aspx. Referred on $15^{\text {th }}$ April 2020.

[3] Monroe, K. B., \& Guiltinan, J. P. (1975). A path-analytic exploration of retail patronage influences. Journal of Consumer Research, 2(1), 19-28.

[4] Arnold, S. J., Oum, T. H., \& Tigert, D. J. (1983). Determinant attributes in retail patronage: Seasonal temporal, regional and international comparisons. Journal of Marketing Research, 20(2), 149-157.

[5] Mason, J. B., Durand, R. M., and Taylor, J. L. (1983). Retail patronage: A causal analysis of antecedent factors. In W. Darden, \& R. Lusch (Eds.), Patronage behavior and retail management (pp. 339-352). New York: North-Holland.

[6] Keng, K. A., \& Ehrenberg, A. S. C. (1984). Patterns of store choice. Journal of Marketing Research, 21(4), 399-409.

[7] Louviere, J. J., \& Gaeth, G. J. (1987). Decomposing the determinants of retail facility choice using the method of hierarchical and international comparisons. Journal of Marketing Research, 63(1), 149-157. 942.

[8] Spiggle, S., \& Sewall, M. A. (1987). A choice set model of retail selection. Journal of Marketing, 51(2), 97-111.

[9] Dawson, S., Bloch, P. H., \& Ridway, N. M. (1990). Shopping motives, emotional states and retail outcomes. Journal of Retailing, 66(4), 408-427.

[10] Burke, R., Bari, R., Harlam, A., Kahn, B. E., \& Lodish, L. M. (1992). Comparing dynamic consumer choice in real and computer- simulated environments. Journal of Consumer Research, 19(1), 71-82.

[11] Weitz, Barton A. (1979), A Critical Review of Personal Selling Research: The Need for Contingency Approaches. In Critical Issues in Sales Management: State-of-the-Art and Future Research Needs, Gerald Albaum and Gilbert A. Churchill, Jr. Eds. Eugene: College of Business Administration, University of Oregon, 76-126.

[12] Saxe, Robert, and Barton A. Weitz (1982). The SOCO Scale: A Measure of the Customer Orientation of Salespeople. Journal of Marketing Research, 19(3), 343-351.

[13] Brown T.J., Mowen, J.C. Donavan, D.T. and Licata, J.W. (2002). The Customer Orientation of Service Workers: Personality Trait Effects on Self- and Supervisor Performance Ratings. Journal of Marketing Research, 34(2), 110-9.

[14] Vandewalle, Donald, Steven P. Brown, William L. Cron, and John W. Slocum (1999). The Influence of Goal Orientation and Self-Regulation Tactics on Sales Performance: A Longitudinal Field Test. Journal of Applied Psychology, 84(2), 249-259.

[15] Gupta, S., \& Cooper, L. G. (1992). The discounting of discounts and promotion 
thresholds. Journal of Consumer Research, 19(12), 401-411.

[16] Bell, D. R., Ho, T., \& Tang, C. S. (1998). Determining where to shop: Fixed and variable costs of shopping. Journal of Marketing Research, 35(3), 352- 369.

[17] Chandon, P., Wansink, B. and Laurent, G. (2000). A benefit congruency framework of sales promotion effectiveness. Journal of Marketing, 64(4), 65-81.

[18] Shim, Soyeon \& Eastlick, M.A. \& Lotz, Sherry. (2000). Assessing the impact of internet shopping on store shopping among mall shoppers and internet users. Journal of Shopping Center Research, 7. 7-43.

[19] Peter J. P., \& Olson J. C. (2002). Consumer Behaviour and Marketing Strategy. Homewood, IL: Irwin McGraw Hill,

[20] Bhatnagar, A., \& Ratchford, B. T. (2004). A model of retail format competition for non-durable goods. International Journal of Research in Marketing, 21(1), 39-59.

[21] Hardesty, D. M., \& Suter, T. A. (2005). E-tail and retail reference price effects. Journal of Product and Brand Management, 14(2/3), 129-136.

[22] Diwakar Gupta, Artur V. Hill, Tatiana Bouzdine-Chameeva. (2006). A pricing model for clearing end-of-season retail inventory. European Journal for Operational Research, 170, 518-540.

[23] Wierenga, B., \& Soethoudt, H. (2010). Sales promotions and channel coordination. Original Empirical Research, 38(3), 383-397. DOI: 10.1007/s11747-009-0161-1.

[24] Yusuf, J. B. (2010). Ethical implications of sales promotion in Ghana: Islamic perspective. Journal of Islamic
Marketing, $\quad$ 1(3), 220-230. DOI:10.1108/17590831011082400.

[25] Teunter, L.H. (2002). Analysis of sales promotion effects on household purchasing behaviour. ERIM PhD Research Series in Management, Erasmus University Rotterdam, p. 262272.

[26] D’Austous, A., \& Landreville, L. (2003). An experimental investigation of factors affecting consumers' perceptions of sales promotions. European Journal of Marketing, 37(11/12), 1746-1761. DOI:10.1108/03090560310495447.

[27] Haans, H., \& Gijsbrechts, E. (2011). One-deal-fits-all?" On category sales promotion effectiveness in smaller versus larger supermarkets. Journal of Retailing, 87(4), 427-443. DOI: 10.1016/j.jretai.2011.05.001.

[28] Mokhtarian P. L. and Tang W. L. (2009). Accounting for Taste Heterogeneity in Purchase Channel Intention Modeling: An Example from Northern California for Book Purchases. Journal of Choice Modelling, 2(2), 148-172.

[29] Dhruv Grewal, Anne L. Roggeveen, \& Jens Nordfält (2017). Future of Retailing. Journal of Retailing,93(1) 1-6.

[30] Ganesha, H. R., Aithal, P. S. \& Kirubadevi, P. (2020). Changes in Consumer Perspective towards Discount at Brick-and-Mortar Stores owing to Emergence of Online Store Format in India. International Journal of Management, Technology, and Social Sciences (IJMTS), 5(1), 43-83.

[31] Ganesha, H. R., Aithal, P. S. \& Kirubadevi, P. (2020). Short-Term Discounting Frameworks: Insights from Multiple Experiments. International Journal of Case Studies in Business, IT, and Education (IJCSBE), 4(1), 8-22.

[32] Ganesha, H. R., Aithal, P. S. \& Kirubadevi, P. (2020). Long-Term 
Discounting Frameworks: Insights from Multiple Experiments. International Journal of Management, Technology, and Social Sciences (IJMTS), 5(1), 84-100.

[33] Ganesha, H. R., Aithal, P. S. \& Kirubadevi, P. (2020). Decentralized Discounting Framework: Insights from an Experiment. International Journal of Applied Engineering and Management Letters (IJAEML), 4(1), 20-40.

$* * * * * * * * * * * * * * * *$ 